\title{
Multinational enterprises and the provision of collective goods in developing countries under formal and informal institutional voids. The case of electricity in Sub- Saharan Africa
}

Article

Accepted Version

Creative Commons: Attribution-Noncommercial-No Derivative Works 4.0

Garrone, P., Piscitello, L. and D'Amelio, M. (2019) Multinational enterprises and the provision of collective goods in developing countries under formal and informal institutional voids. The case of electricity in Sub-Saharan Africa. Journal of International Management, 25 (2). 100650. ISSN 1075-4253 doi: https://doi.org/10.1016/j.intman.2018.09.002 Available at https://centaur.reading.ac.uk/79820/

It is advisable to refer to the publisher's version if you intend to cite from the work. See Guidance on citing.

To link to this article DOI: http://dx.doi.org/10.1016/j.intman.2018.09.002

Publisher: Elsevier

All outputs in CentAUR are protected by Intellectual Property Rights law, including copyright law. Copyright and IPR is retained by the creators or other copyright holders. Terms and conditions for use of this material are defined in the End User Agreement. 


\section{www.reading.ac.uk/centaur}

\section{CentAUR}

Central Archive at the University of Reading

Reading's research outputs online 
Multinational enterprises and the provision of collective goods in developing countries under formal and informal institutional voids. The case of electricity in Sub-Saharan Africa 


\begin{abstract}
Despite their unprecedented growth, developing countries still face severe problems in the provision of collective goods. Electricity, whose provision is scarce or unreliable in most developing regions, especially in Sub-Saharan Africa, is an emblematic case. The reason for this shortage is not only imputable to the lack of effective formal institutions, but also to the inefficacy of informal institutions in enabling alternative solutions for the production, transmission and distribution of electricity. We claim that in this context of "double institutional void", Foreign Direct Investment (FDI) and multinational enterprises (MNEs) can play a decisive role. However, their effectiveness depends on both the formal and informal institutional proximity between the home and the host countries. Our empirical analysis relies on panel data models run on a sample of pairs of home-host countries, the latter of which are all from Sub-Saharan Africa (SSA), observed from 2005 to 2011.
\end{abstract}

Keywords: Inward FDI; electricity provision; formal and informal institutions; institutional proximity; institutional void; Sub-Saharan Africa 


\section{Introduction}

The impact of multinational enterprises (MNEs) and foreign direct investments (FDI) on host countries, especially developing countries, has been widely debated and generated substantial controversy (e.g., Kolk et al., 2018; Oetzel and Doh, 2009). On the one hand, MNEs and FDI promote economic growth by raising domestic savings, transferring technology and knowledge, increasing domestic competition and stimulating entrepreneurship (Caves, 1974; Teece, 1977); on the other hand, they may crowd out local firms, introduce inappropriate technologies, constrain potential technology and knowledge spillovers, and reduce domestic tax revenues because of transfer price and profit manipulation (De Backer and Sleuwagen, 2003; Haddad and Harrison, 1993). Such a controversy about the impact of MNEs is not limited to economic performance, as it also covers non-economic dimensions of development, such as environmental and social issues (Abdouli and Hammami, 2017; Hubler and Keller, 2010).

We aim to join this debate by investigating the role that FDI might play in promoting a specific dimension of development, namely, the access to electricity of a local population (see also, D'Amelio et al., 2016; Sesan et al., 2013). In fact, access to modern energy services, particularly electricity, together with other commodities, functions and services, such as drinkable water, education, transportation, communication, and health, is a collective good ${ }^{1}$, and its provision is necessary to enhance standards of living, to run business activities, and to the functioning of public services (e.g., Kebede, Kagochi, and Jolly, 2010; Khavul and Bruton, 2013; Ahlborg et al., 2015). However, the International Energy Agency (IEA) estimates that 1.3 billion people in developing countries, which is equivalent to 17 per cent of the global population, had not access to electricity in 2013. Nearly 97 per cent of those people live in Sub-Saharan Africa (SSA) and developing Asia (IEA, 2014). For this reason, in 2011, the United Nations General Secretary launched the Sustainable Energy for All Initiative (SE4All) with one of its objectives being the universal access to electricity by 2030 .

A few structural characteristics of developing countries, coupled with low income, trigger a vicious circle between energy poverty and development slowdown (see Sovacool, 2012, for a review of energy poverty effects and structural causes). For-profit electric utilities tend not to deploy the electricity infrastructure

\footnotetext{
${ }^{1}$ We name access to energy "collective good", because we refer to the definition of collective goods used by Boddewyn and Doh (2011), i.e." those commodities, functions, and services that provide positive externalities such as health, education, communication, transportation, water, and electricity to local collectivities". More in detail, communities that obtain access to modern energy services can provide their members with public goods such as street lighting, enhanced safety or education. However, while energy generates important externalities, a significant part of its benefits such as cooking, indoor lighting, heating are affected by so-called "rivalry"; thus, it is an impure public good, or a collective good in the words of Boddewyn and Doh (2011). For a re-conceptualization of public goods, see also Kaul (2001) and Kaul and Mendoza (2003).
} 
when the potential customers have a low income, and when investment and operation costs are high due to the geographic dispersion of population, the presence of rural areas, and/or topographical challenges for connectivity. However, public sector players are unlikely to be the solution in these countries, because they are financially constrained and tend to privilege other urgent needs or to focus on urban areas. In turn, without access to modern forms of energy, households miss opportunities for income-generation activities, spend an important part of their time or financial budget in supplying the fuel, are not able to study at home, and suffer health problems owing to the use of traditional biomasses. In other words, population slides away even more from the development path, and the willingness to pay for electricity further decreases, a fact that jeopardizes the incentives to provide access to electricity. ${ }^{2}$

In order to assess whether inward FDI may play a role in breaking the vicious circle that keep developing countries in energy poverty conditions, we build a model for the determinants of electricity access. Specifically, we adopt a conceptual framework that relies on two research traditions, namely the transaction cost economics (TCE) of infrastructure provision (Ostrom et al., 1993; Levy and Spiller, 1994; Henisz and Zelner, 2001; Henisz, 2002; Spiller, 2013), and the institutional theory of organizations $^{3}$ (for a recent literature review with specific reference to emerging countries, see Rottig, 2016). While TCE studies have highlighted that well-functioning formal and informal institutions are necessary to remedy market and governmental failures in the infrastructure sectors, institutional theorists have emphasized that the social environment and its formal and informal "rules of the game" affect an organization's structure and actions. Specifically, formal institutions refer to rules that are observable through written documents, or rules that are determined and executed through formal positions, such as authority or ownership; they include juridical rules, explicit incentives, contractual terms and economic

\footnotetext{
${ }^{2}$ The last half of the twentieth century has witnessed a further slowdown in infrastructure investments and maintenance for the production, transmission and distribution of electricity in Sub-Saharan Africa (Robbins and Perkins, 2012). Although the reasons for this decline are complex and vary across countries, the decrease of state revenues stemming from the commodity price crisis of the 1970s, and the consequent political and economic instability are likely to have reduced the diffusion of modern forms of electricity.

${ }^{3}$ We are aware that the societal role of MNEs can be studied adopting different theoretical lens (see Forsgren, 2017). However, echoing Forsgren (pp. 144), "the (institutionalization) theory is quite mixed from a societal point of view. One strand within the theory emphasizes the/a multinational firm's tendency to adapt to external institutions in terms of rules, norms and values. In that sense, it has a quite passive or reactive role. But [...] other themes in the theory emphasize that multinational firms can have a much more proactive role vis-à-vis society. These themes leave room for the idea that powerful multinationals can shape the environment in such a way that they maximize their own short-term profits instead of being beneficial for society in the long- run. The outcome hinges on the power balance between the multinational firm and the surrounding society." Thus, as we are dealing with the role of institutions on the one hand, and the MNEs' search for legitimacy through market and nonmarket strategies, on the other, we believe our context is particularly appropriate to understand the "balance between the multinational firm and the surrounding society". We are particularly grateful to an anonymous Referee who stimulated us to better justify our choice.
} 
rules/property rights (North, 1990). Informal institutions are non-codified systems of shared values and collective understanding, which shape cohesion and coordination among individuals in a society (Holmes et al., 2013; DiMaggio and Powell, 1983).

Electricity shortage could stem from the failure of formal institutions to ensure that governments provide electricity infrastructures or regulate private utilities (Gillanders, 2014; Henisz, 2002; Levy and Spiller, 1994); however, electricity shortage could also derive from the inability of informal institutions to promote self-organized collective actions, i.e. cooperatives and non-profit organizations (NGOs), which develop and operate decentralized systems for the generation, transmission and distribution of electricity (Hansmann, 1996; Ostrom et al., 1993; Teegen, 2003). We argue that, within this context, and particularly when both formal and informal institutions fail to develop lasting solutions for the provision of electricity to the local population, inward FDI and foreign MNEs may actively participate in the development, maintenance and operation of an electricity infrastructure, alone or in partnership with forprofit local organizations or NGOs (Boddewyn and Doh, 2011).

Foreign MNEs engage in electricity provision following both market and non-market strategies. As far as market strategies, first, electricity provision is the core mission of foreign utilities that enter liberalized local markets by leveraging resources and competences that have cumulated in their home countries and on international markets (Mbalyohere et al., 2017). Second, MNEs, especially from energy-intensive industries (like those in the mining industries, e.g. Banerjee et al. 2014, pp. 43-55) have traditionally invested in generation and transmission infrastructures to grant a reliable and cost-effective supply for their own operations. In fact, some of them are abandoning the traditional "enclave" approach and do cooperate with local governments to provide electricity infrastructures that serve both their operations and local users (Robbins and Perkins, 2012; Toledano, 2012; Banerjee et al. 2014, pp. 57-80). Additionally, the activism of MNEs in electricity provision could reflect a non-market strategy, since promoting the local population's access to electricity is a means through which MNEs gain legitimacy with local stakeholders, thus raising the likelihood of success in their own core businesses (Holburn and Zelner, 2010).

However, we also claim that to properly assess the impact of MNEs in foreign countries, it is important to take into account the institutional environment of their country of origin and, specifically, the institutional proximity with the host country. In fact, managers' competences depend on their specific formal and informal institutional setting (Kostova and Zaheer, 1999); thus, we expect that those MNEs that are more effective in developing electricity infrastructure and raising access to electricity will be those from countries that are institutionally closer to the host countries (Cuervo-Cazurra and Genc, 2008). 
In this paper, we focus on Sub Saharan Africa (SSA), as this is one of the regions in the world that, according to UNCTAD data, has experienced the greatest increase in the flows of inward foreign direct investment (FDI) over the last decade, namely a 120 per cent increase from 2005 to 2014. In fact, a stable economic growth, a burgeoning middle class, an increasing purchasing power and a youthful population has led Ernest and Young to rank SSA as the second most attractive region in the world in 2014 (E\&Y, 2014). Nevertheless, the same region, with 68 per cent of the population (i.e., 634 million people) without access to electricity, has the lowest access to electricity rate in the world (IEA, 2014). In this context, investigating whether FDI and MNEs can play a role in stimulating the long-term development of the region seems to be particularly appropriate.

In order to test the impact of inward FDI and MNEs on the access to electricity, and the contingencies related to the quality of the host and home countries' institutions, and their proximity, we adopt the so called infrastructure deployment model introduced by Henisz and Zelner (2001) to study the institutional determinants of telecommunication infrastructures. Our findings, obtained by means of panel data techniques, confirm that FDI can raise the access to electricity of a local population, depending on the quality of formal and informal institutions in both the country of origin and the country of destination of the investment. Specifically, we find that FDI positively impact the access to electricity of the local population especially in those countries where both formal and informal institutions are weak. Additionally, this is more likely to be the case when FDI come from countries that are institutionally closer to the host country.

We believe our results contribute to the debate on the impact of MNEs on developing countries and the role of (formal and informal) institutions therein, by focusing on an important prerequisite for development - namely, the provision of electricity.

This article is organized as follows. Our conceptual framework is presented in section 2. Section 3 illustrates the data and the variables employed in our empirical analysis. Section 4 describes the model adopted to test our hypotheses. Sections 5 and 6 present the results and robustness checks, respectively. Finally, section 7 concludes and discusses some policy and managerial implications of our results.

\section{The role of institutions, FDI and MNEs in the provision of electricity. A conceptual framework}

The provision of infrastructures and other collective goods has been widely investigated through conceptual frameworks that combine TCE with a thorough analysis of institutions across different geographic contexts (e.g. Ostrom et al., 1993; Levy and Spiller, 1994; Henisz and Zelner, 2001; Henisz, 2002; Spiller, 2013). 
Infrastructure assets are highly specific and not re-deployable; they enjoy important economies of scale and scope, and have a broad range of domestic users (Levy and Spiller, 1994). The combination of these features generates transaction costs and makes infrastructures highly vulnerable to expropriation risks, unless the hold-up problem is alleviated through appropriate formal institutions (Levy and Spiller, 1994; Henisz, 2002). If formal institutions are well-designed and protected, the State provides and/or regulates electricity infrastructures. However, another body of TCE studies emphasize that centralized institutional arrangements are unlikely to efficiently coordinate the multiple independent actions that are necessary to develop, maintain and operate infrastructures (Ostrom, 1990, pp. 38-39), partly because they rarely adapt to specific local circumstances and needs (Ostrom et al., 1993, pp. 141-156). More generally, in developing countries, the functioning of formal institutions can suffer to various degrees when the judicial system is inefficient, regulation is misguided and information is not reliable, thus generating formal institutional voids (Khanna and Palepu, 1997). When this is the case, national governments are likely to be ineffective in providing and/or regulating electricity infrastructures.

In such a context of formal institutional voids, informal institutions can play a crucial role in supporting the provision of collective goods (Teegen, 2003). In fact, informal institutions may be seen as enabling conditions and they have become crucial for the economic activity, especially in emerging and developing markets (Khanna and Palepu, 2010). In the electricity sector, in particular, informal institutions may enable self-organized collective actions, namely NGOs or electricity cooperatives, which are owned and managed by a group of consumers or by local communities, and often supplant State-owned and/or regulated utilities (Ostrom et al., 1993; Hansmann, 1996).

Informal institutions emerge in response to repeatedly encountered social and/or economic problems, and they mirror the social capital of the country, meant as the "goodwill available to individuals or groups, whose source lies in the structure and content of the actor's social relations" (Adler and Kwon, 2002: 23). A higher social capital corresponds to stronger links among individuals and/or groups, thus lowering transaction costs, favoring cohesiveness, and facilitating the pursuit of collective goals (Sandefyr and Laumann, 1998). Thus, informal institutions are related to the social structure, namely the level of trust and collectivism among the individuals or groups that compose a society (Leana and Van Buren, 1999; London and Hart, 2004). Trust is a "generalized expectancy held by an individual that the word, promise, oral or written statement of another individual or group can be relied upon" (Rotter, 1980, p.1). In economic terms, trust is a mechanism that mitigates (against) the risk of opportunistic behavior among those engaged in various types of economic transactions (Bigley and Pearce, 1998). For this reason, trust is a key motivational source of social capital (Adler and Kwon, 2002). On the other hand, 
collectivism, defined as the willingness and ability of individuals to define collective goals that are enacted collectively, is essential for the generation of social capital (Leana and Van Buren 1999).

This implies that collectivist and trust-based societies, where community members trust each other and act on the basis of group rationality rather than individual rationality, are more likely to self-organize and to be successful in the provision of collective goods (Holmes et al., 2013; Teegen, 2003). However, whether a common action can be effectively organized internally by communities, namely by citizens' self-governed associations, is highly contingent to the social setting (Ostrom, 1990, pp. 55-57). As previously described for formal institutions, when informal institutions are poorly developed, the country experiences an informal institutional void.

Thus, the provision of electricity in a country depends on the quality and strength of both formal and informal institutions. Table 1 illustrates the available arrangements to provide electricity under different combinations of formal and informal institutions. Specifically, infrastructures include national grids that connect large production nodes to regions and large consumption areas over long distances; mini grids that connect consumers belonging to smaller local communities to local production plants, and off-grid systems that ensure autonomy of the end-users (IEA, 2014; Banerjee et al. 2014, pp. 43-55). National grids cannot be deployed and managed by decentralized local players, such as NGOs and cooperatives. However, those organizations that engage local consumers and other local players have an advantage in adapting mini and off-grid systems to local needs and circumstances.

In situations in which both formal and informal institutions are strong (North-West cell in Table 1), both State-owned or regulated utilities and NGOs or cooperatives can develop and operate electricity infrastructures of different kinds. The North-East and South-West cells in Table 1 represent situations in which strong formal institutions balance weak informal institutions and vice versa. Strong formal institutions are sufficient to ensure that State-owned or regulated utilities provide electricity, mainly through national or mini grids. On the other hand, stronger informal institutions promote the formation of NGOs and cooperatives that mainly supply electricity through off- and mini-grid systems. Finally, in a context of double institutional void (South-East cell in Table 1), arrangements such as State ownership, regulation, NGOs or cooperatives are unlikely to be effective, and foreign MNEs can emerge as important actors in the provision of electricity.

[Insert Table 1 here] 
Other studies (e.g., D’Amelio et al., 2016) have already shown that when formal institutions are weak, MNEs actively participate in the development of infrastructures for the provision of electricity to the local population. We claim that this is even more the case when the informal institutions are also weak, that is, where no other body is in place to provide electricity to the local market.

In fact, the engagement of foreign MNEs with electricity infrastructure may be associated to the company's market or non-market strategies (Doh et al., 2012). On the one hand, as far as market strategies, MNEs may build electricity infrastructure as part of their core product/service (Mbalyohere et al., 2017). As acknowledged by Buckley and Boddewyin (2015), "such internalization of the markets for public goods and societal functions is often necessary for the production and distribution of the private goods, which attracted MNEs to these markets in the first place". For example, the Electricite de France Group (EDF), a global leader in the power sector, signed several agreements with national governments and other MNEs to cooperate in the improvement of the electrification rate in several Sub-Saharan countries, such as Botswana, Mali, South Africa and Senegal. This has been done through the development of on-grid and mini-grid systems. In other industries, like manufacturing and mining, companies may engage in electricity infrastructures because they need energy to run their business activities and supply their products (Robbins and Perkins, 2012; Toledano, 2012; Banerjee et al., 2014). On the other hand, MNEs could supplement governmental and non-governmental activities in the provision of electricity infrastructures as part of their non-market strategies. Indeed, corporate social responsibility and corporate political activities may be instrumental to gain the legitimacy that is necessary to countervail the liabilities of being a foreign as well as a profit-driven company. By providing electricity to the local population, MNEs internalize societal failures (i.e. those associated to society's non market subsystems - political, social and cultural - that are subject to failures just like economic markets, see Buckley and Boddewyn, 2015), and show commitment toward the country in which they are investing, thus gaining legitimacy with local stakeholders, e.g., civil society, politicians and local representatives (Holburn and Zelner, 2010). In fact, legitimatization with local stakeholders is fundamental to increase the chances of survival and success of foreign firms on the host market (DiMaggio and Powell, 1983). An example is AngloGold Ashanti, a South African multinational mining company that operates in Guinea and which, as a result of villagers' protests in 2012, built an electric power line from one of its mining plants to the nearby town, in order to gain legitimacy with the villagers and guarantee their business activities (Toledano, 2012).

Accordingly, our first hypothesis states as follows: 
H1. The presence of FDI and MNEs is more likely to positively impact the access to electricity of the local population when both formal institutions and informal institutions of the host country are weak(i.e. the host country suffers from a double institutional void).

However, institutional theory suggests that MNEs must conform to the rules and requirements of the local social environments in which they operate in order to be perceived as legitimate (Rosenzweig and Singh, 1991; Westney, 1993). In fact, organizations that do not conform to the rules, values and beliefs lose the support of, and acceptance by, the surrounding society in which they are embedded (Scott, 2014). Hence, unless MNEs understand and correctly interpret the formal regulatory and informal normative and cultural rules of a foreign institutional environment, they are unlikely to succeed on that market (Kostova and Zaheer, 1999; Scott, 2014). Information asymmetry is acute as it is difficult for a foreign firm to fully understand local practices; additionally, both external and internal uncertainty surrounding MNE investments is high because of the typical lack of stability in the host less developed countries (Buckley and Boddewyn, 2015).

Accordingly, previous studies have already shown that the effectiveness of MNEs in compensating the inability of host country institutions to provide electricity is strongly influenced by the proximity between the formal institutional context of the country of origin of the MNE and the formal institutional environment of the host country (D'Amelio et al., 2016). When formal institutions of the host and the home country presents some similarities, MNE managers are likely to have already developed at home the capability to deal with weak formal institutions, the resilience against and the adaptability to the political turbulences and uncertainties in the region (Mbalyohere and Lawton, 2018), and are more effective in identifying key actors to form winning coalitions in the host country (Cuervo-Cazurra and Genc, 2008; Holburn and Zelner, 2010; De Beule et al., 2014).

We argue that the same situation should in principle hold also when considering informal institutions of the host country, and their proximity with the relevant institutions between the host country and the MNEs' home country. In fact, managers from countries with a low attitude toward collectivism and trust are familiar with the inability of local communities and NGOs to compensate for the weakness of national governments in implementing sound and lasting actions for the provision of electricity to local populations. For this reason, compared with MNEs from countries with strong informal institutions, MNEs from informal and institutionally weak countries are more likely to have already developed inhouse alternative solutions for the provision of electricity to the population of the countries where they operate. Moreover, MNEs from institutionally similar countries are likely to find it easier to adapt to the 
unique institutional environments of the host developing countries (Rottig, 2016). Accordingly, our second hypothesis states as follows:

H2. The presence of FDI and MNEs in a country affected by formal and informal (double) institutional void is more likely to positively impact the access to electricity of the local population when they come from countries that are institutionally closer to the host country.

\section{Data and descriptive statistics}

\subsection{Sample}

Our sample is composed of pairs of 73 home countries and 15 host countries from Sub-Saharan Africa, which are observed from 2005 to 2011 . Table 2 reports the list of sample host countries and host-home country pairs.

In order to deal with missing data (especially for the variables that measure the access to electricity for local populations, and for data on inward FDI), we adopted multiple imputation techniques ${ }^{4}$ (Allison, 2001), and this led to a final balanced sample of 1,547 observations.

Given the nature of our data, we adopted an econometric analysis based on panel data techniques.

[Insert Table 2 here]

\subsection{Dependent Variable}

Access to Electricity Growth. The access to electricity rate has been sourced from the World Energy Outlook of the IEA. Namely, our dependent variable is the annual growth of the percentage of households with access to electricity (Source: IEA). According to the definition provided by IEA, access to electricity comprises consumption of a minimum level of electricity, set equal to 250 kilowatt-hours (kWh) per year for rural households, and to $500 \mathrm{kWh}$ per year for urban households (IEA, 2014). This variable includes infrastructural and non-infrastructural solutions for the provision of electricity (e.g., diesel generators) and mainly refers to the supply side of electricity access. Thus, we also included control variables that

\footnotetext{
${ }^{4}$ With multiple imputation, missing values are drawn from a distribution of observed variables, including the variables at stake. Multiple imputation does not entail interpolation from contiguous values. Instead, it is generated by chained equations, an option that is suitable to deal with a high proportion of missing data (Allison, 2001). Finally, in order to guarantee the consistency of the imputed data, we removed all the paired countries with less than 3 observations per variable over the 7 years.
} 
capture the determinants of the electricity demand and obstacles to the development of electricity infrastructures (see below).

Table 3 shows the data on the access to electricity from 2005 to 2011 in the host countries of our sample. Overall, the access to electricity increased in all Sub-Saharan countries, with peaks in Namibia (+26\%), Angola and Ghana (both $+23 \%$ ). The countries with the highest rate of access to electricity in 2011 are Mauritius (99\%) and South Africa (85\%); the most problematic countries are the Democratic Republic of Congo (9\%), Uganda (15\%) and Kenya (19\%).

[Insert Table 3 here]

\subsection{Explanatory variables}

FDI per capita. Bilateral inward FDI stocks disaggregated according to the country of origin and the destination of the investment have been adopted to measure the presence of foreign MNEs (Source: UNCTAD). Since inward FDI stock is an extensive variable, which varies according to the country's size, and our dependent variable is expressed as a percentage of population, we considered the bilateral FDI per capita 5 .

Table 4 shows the distribution of the FDI per capita according to the region of origin. The European Union appears to be the main investor (28\% of the total FDI per capita), followed by North America (19\%), South-East Asia (15\%) and SSA (11\%). The Chinese FDI ranks sixth, with a total amount of \$19k per capita ( $7 \%$ of the total FDI per capita) ${ }^{6}$.

\section{[Insert Table 4 here]}

Formal Institutional Void. The formal institutional void in a host country is measured considering the six World Bank's Worldwide Governance Indicators (WGIs) on a yearly basis, namely regulatory quality, control of corruption, voice and accountability, rule of law, governance effectiveness and political stability, and absence of violence and terrorism. We have chosen these indicators as they are

\footnotetext{
${ }^{5}$ We are aware that FDI stocks may often be a biased measure of MNE affiliate activity, for example when (as in tax haven countries) FDI do not generate actual productive activity. See Beugelsdijk et al. (2010) for an exhaustive discussion on this issue.

${ }^{6}$ A possible explanation for the small amount of Chinese FDI could be that Chinese companies rely heavily on governmentsponsored projects, and this makes the distinction between FDI and official assistance ambiguous. For instance, investments by Chinese state-owned enterprises (SOEs) are included in the definition of official flows of development assistance if they receive subsidized state financing of the export credits (World Bank, 2015).
} 
good proxies for the institutional mechanisms that, according to Bergara et al. (1998), are necessary to guarantee the feasibility of infrastructure investment (for further details on the definition of the formal institutional dimensions, see Appendix A.1). However, as there is not a univocal correspondence between the WGIs and these four mechanisms, all (the) six WGIs have been considered. In addition, due to the high correlation among these indicators (coefficient $>0.7$ and $p<0.01$ ) and in line with the previous literature (e.g., Farla et al., 2016), we performed a factor analysis in order to have an indicator of the degree of formal institutional void of a host country, as shown in Table 5. This variable takes a high value when the country is affected by a severe formal institutional void, and a lower value for a higher quality of formal institutions.

\section{[Insert Table 5 here]}

Informal Institutional Void. As illustrated in Section 2, a country's social capital is a major component of local informal institutions. Social capital is weaker where the degree of collectivism and trust are lower (or, conversely, when individualism and distrust are higher). In order to measure the void of informal institutions in the host country, we adopted the following two variables: (a) institutional collectivism, sourced from the Global Leadership and Organisational Behaviour Effectiveness (GLOBE) project, and (b) the degree of interpersonal trust, sourced from the World Value Survey (WVS).

As far as institutional collectivism, it reflects "the degree to which organizational and societal institutional practices encourage and reward the collective distribution of resources and collective action" (House et al., 2004: 30). Thus, high institutional collectivism corresponds to strong informal institutions, i.e. to a low level of informal institutional voids, while low collectivism reveals high informal institutional voids. Note that the GLOBE dataset hosts a continuous country-level and time invariant indicator for institutional collectivism.

Concerning the degree of interpersonal trust in a society, it explains why actors tend to cooperate in some settings but do not cooperate in other settings (Cox et al., 2009; Ostrom et al., 1993). A high level of interpersonal trust corresponds to small informal institutional voids, while low trust reveals high informal institutional voids. Specifically, the WVS dataset reports the country-level rate of respondents who agree that "Most people can be trusted" for the 2005-'09 period, with different years for different countries. In principle, trust and collectivism could exhibit some degree of longitudinal variance in the panel time window. However, we are confident that the underlying variations are small, because informal 
institutions are endogenous to indigenous societies, a fact that makes them evolve slowly (Boettke et al., 2008).

Formal and Informal Institutional Proximity. In order to proxy institutional proximity between the host and the home country, we first calculated the formal and informal voids (i.e. the quality of the formal and informal institutions) for the home country (using the same procedures and sources presented above for the host country). We then measured the dyadic distance between the level of institutional void in the home and host countries by means of the Mahalanobis method ${ }^{7}$. Finally, by inverting the measures of institutional distance, we obtained institutional proximity between the home and host country, both for formal and informal institutions ${ }^{8}$.

\subsection{Control Variables}

The statistical analysis includes a number of control variables. First, as the growth rate in the access to electricity is largely dependent on economic resources (Ahlborg et al., 2015), we introduced two dummies accounting for the income level of the host country, namely, low-income country (LIC) and lower middle-income country (LMIC). The upper middle-income country (UMIC) dummy represents the baseline. The classification comes from the World Bank 9 .

In addition, in order to control for the host country's economic structure and to mitigate the lack of information about the sector of the inward FDI, we included industry and service value added variables, both of which are expressed as percentages of the gross domestic product (GDP) (Source: World Bank's Development Indicators). Specifically, industry value added covers mining, manufacturing, construction, electricity, water and gas, while service value added comprises wholesale and retail trade (including hotels and restaurants), transport, government, financial, professional and personal services, such as education, health care and real estate services. The two variables take on a low value if the country is specialized in agriculture, husbandry, forestry and fishing.

Since, ceteris paribus, it is more difficult to increase access to electricity when a population lives in a rural area, we also included the variable Rural population, measured by the annual percentage of

\footnotetext{
${ }^{7}$ It may be worth noting that the Mahalanobis method is generally considered a better choice than the more traditional Euclidean method, as it is scale invariant and it takes into consideration the variance-covariance matrix (Berry et al., 2010). ${ }^{8} \mathrm{We}$ are aware that, given that nearly half of the FDI in SSA in the period considered come from the EU and North America, the concept of (formal and informal) institutional similarity is likely to assume a relative rather than an absolute nature. In other words, we could talk about greater or lower similarity, rather than similarity per se. We'd like to thank an anonymous reviewer for pointing out this important issue.

${ }^{9}$ It may be worth noting that the World Bank classification is built, on a yearly basis, using the nominal gross national income (GNI) per capita. See http://data.worldbank.org/about/country-and-lending-groups accessed on 15 June 2016.
} 
population living in a rural area, and Population density, measured by the number of people per square kilometer of land area. Both variables come from the World Bank's Development Indicators.

Furthermore, as electrification shows scale effects, we control for the size of the country (Population), expressed in millions of people (the source of data is the World Bank's Development Indicators).

Finally, in order to capture time varying macroeconomic shocks and unobservable country pair specific factors, we added time and country pair dummies.

Table 6 reports the descriptive statistics and correlation matrix of the variables considered. The overall pattern does not reveal any multi-collinearity.

[Insert Table 6 here]

\section{Methodology}

In order to analyze the determinants of the access to electricity by local population, we adopt a growth model that links infrastructure deployment to institutions (see Henisz and Zelner, 2001). Equation (1) represents our baseline.

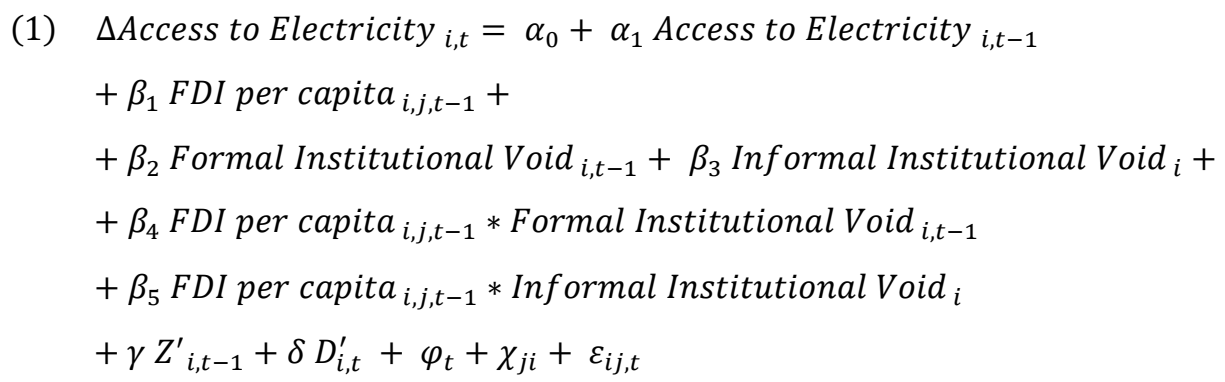

where $\mathrm{i}$ is the host country, $\mathrm{j}$ is the home country, $\mathrm{t}$ is the year, $\varphi_{\mathrm{t}}$ and $\chi_{\mathrm{ji}}$ are the unobservable year and country-pair fixed effects, respectively; $\varepsilon_{\mathrm{ij}, \mathrm{t}}$ is the i.i.d. disturbance term. AAccess to electricity ${ }_{i, t}$ is the difference in the access to electricity rate between $\mathrm{t}$ and $\mathrm{t}-1$ for host country $\mathrm{i}$. Access to electricity $y_{i, t .1}$ is the lagged dependent variable in level. Equation (1) is a reduced form specification of the dynamic investment model (see Bond and Van Reenen, 2007), since the growth of access rate is a proxy of investment, and the lagged access rate is a proxy of the installed capital stock. The equivalent model in which the dependent variable is the access rate in level can easily be obtained by adding the/a lagged dependent variable, i.e. Access to electricity ${ }_{i, t} \cdot$, to both sides of the equation and re-parametrizing its coefficient into $1+\alpha_{1}$.

The explanatory variables are FDI per capita ${ }_{i, j, t \cdot 1}$, Formal Institutional Void $_{i,}$ and Informal Institutional Void $_{i,}$. They are included in the level and in the cross products. We have adopted a one-lag model 
specification to preserve the maximum possible number of degrees of freedom available for the estimates, but this specification choice does not imply that the response of access to electricity to FDI should take just one period. The presence of the lagged depend variable ensures that the response of access to electricity to FDI is not compelled to take just one period, it can take as many periods as necessary. While the $\beta_{1} \ldots \beta_{5}$ coefficients capture the short-run marginal effects of the FDI and institutions, the $\alpha_{1}$ coefficient encompasses the long-run dynamics of the relationships between FDI, institutions and access to electricity (see also Garrone and Grilli, 2010). D'Amelio et al. (2016) simulate a similar dynamic model, and show that two or three years are the typical response time.

$Z_{i, t-l}^{\prime}$ is the control vector (population, rural population, population density, industry value added and service value added), lagged by one period, while $D^{\prime}{ }_{i, t}$ is the vector of the $L I C$ and $L M I C$ dummies.

Equation (1) was then extended by introducing formal institutional proximity and informal institutional proximity, both linearly and in interaction with FDI per capita, as shown in Equation (2).

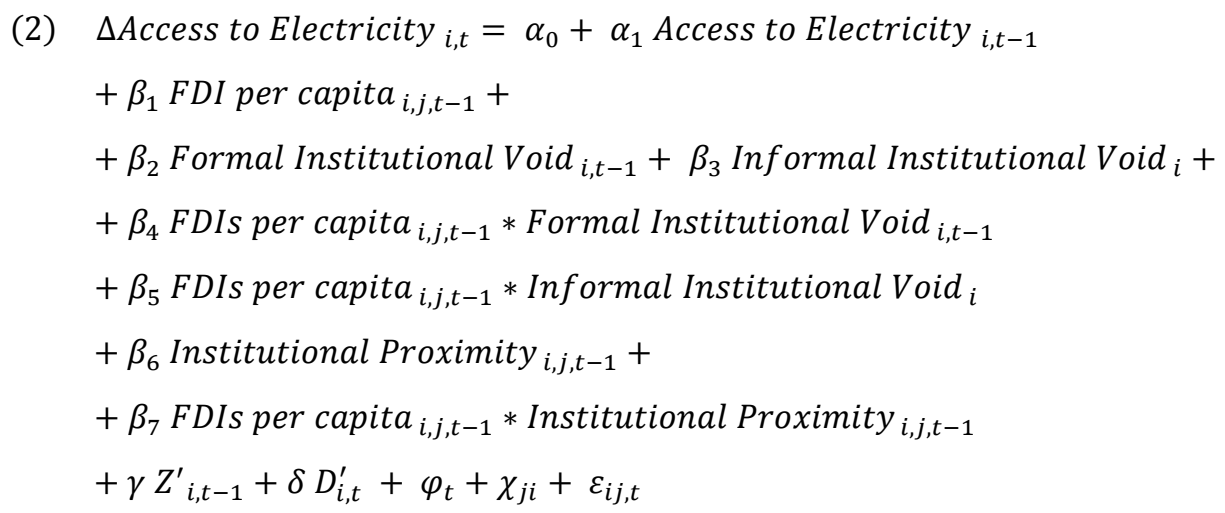

According to the literature on dynamic panel data, we used the Arellano-Bover/Blundell-Bond Generalized Method of Moments estimator (system GMM) (Arellano and Bover, 1995; Blundell and Bond, 1998). Specifically, we adopted a two-step method as it is asymptotically more efficient than the one-step method (Baltagi, 2005); the bias in the standard errors was fixed by means of Windmeijer's (2005) correction procedure. We controlled for the endogeneity of the lagged dependent variable, the country's economic structure, the country's income level, FDI per capita, and the level of formal and informal institutional voids of the host country. Furthermore, we added some external instruments treated as predetermined variables, e.g. the degree of a country's globalization; the level of human capital; the 
internal ethnic and religious tensions, and other dimensions of economic development not included in the model, due to multi-collinearity problem ${ }^{10}$.

Finally, it is worth observing that before computing our estimates, we ran a reverse causality analysis (using the baseline presented in Equation (1)) to rule out the possibility that the presence of electricity infrastructure has attracted FDI, and not the other way around. Results confirm that causality runs from inward FDI to access to electricity growth ${ }^{11}$.

\section{Results}

Table 7 reports our estimates. In Models (1), (2) and (3), informal institutional void has been measured by the degree of institutional individualism, while in Models (4), (5) and (6), informal institutional void has been measured by the degree of distrust. Models (1) and (4) represent the baseline, where we test the impact of FDI per capita on the access to electricity growth, contingent on the degree of formal and informal institutional voids in the host country. We then add formal institutional proximity, both in level and in interaction with FDI per capita in Models (2) and (5), respectively. Likewise, we added informal institutional proximity, both in level and interacted with the FDI per capita, in Models (3) and (6).

[Insert Table 7 here]

The lagged dependent variable in level is negative and significant in all the models, meaning that the higher the electrification rate at time $\mathrm{t}-1$, the lower the growth rate of the access to electricity at time $\mathrm{t}$. All the control variables show a steady and significant sign across all the models. Specifically, the country size (Population) and the population density contribute positively to the access to electricity growth, while a high rate of rural population curtails it $(\mathrm{p}<0.01)$. This confirms that an increase in the access to electricity rate mainly occurs through the development of an electricity infrastructure, which is characterized by economies of scale and density. The LIC dummy variable is negative and significant $(p<0.01)$, possibly because an important part of the economy of these countries is represented by the mining sector, which leads to limited benefits for the local population in terms of access to electricity

${ }^{10}$ The level of a country's globalization has been proxied with the KOF index of globalization introduced by Dreher (2006). The level of human capital has been measured by the human flight and brain drain variable (Source: Fund for Peace). The internal tensions have been represented by the group grievance variable (Source: Fund for Peace). Finally, economic development has been expressed by the poverty and economic decline variable that aggregates dimensions such as unemployment, youth unemployment, economic deficit, government depth, inflation, purchasing power and GDP growth (Source: Fund for Peace).

${ }^{11}$ The results of the reverse causality analysis has not been reported for the sake of space; however, they are available upon request. 
(World Bank, 2015). In fact, a recent study of the World Bank on more than four hundred mining projects in the SSA has shown that mining companies often use their own generators or source electricity from the national grid, while only rarely they sell excess power to the grid or electrify the neighboring rural population (World Bank, 2015) ${ }^{12}$. For this reason, the negative effect is not that surprising. Finally, as expected, a higher level of service value added increases the growth of the access to the electricity rate, while industry value added is not significant.

The estimates in Table 7 confirm that countries lacking effective institutions experience a slower growth in access to electricity (D'Amelio et al., 2016). However, the effect of individual institutional components seem to depend on the specifications adopted. In fact, we find that the direct effect of the degree of individualism on the growth of the access to electricity is negative (Informal institutional void is negative and significant at $\mathrm{p}<.01$ in models $1-3)$. The GLOBE indicator that measures institutional collectivism captures the capability of societies to enact collective action practices. Indeed, high institutional individualism increases both the costs of monitoring the actions of each other, and the probability of free riding (Ostrom, 2000). This suggests that societies in which community members are able to cooperate are more likely to enable electricity cooperatives and NGOs that are effective in the provision of electricity. On the other hand, the degree of interpersonal trust is not found to be sufficient for fostering the creation of alternative solutions for the provision of electricity to local population (Informal institutional void is never significant in models 4-6). However, trust is typically limited to kinship networks in many developing countries (Ostrom et al. 1993, p. 63), and single family and ethnic groups may not have the necessary technical and business capabilities to create and manage non-profit electricity providers. Once controlling for the degree of individualism, formal institutions are unlikely to play a significant role by themselves (Formal institutional void is not significant in models 1-3), while on the contrary once controlling for trust, the strength of formal institutions appear to drive electricity provision (as Formal institutional void is negative and significant at $\mathrm{p}<.01$ in models 4-6). As far as FDI per capita, it does not seem to affect our dependent variable in Model (1), but interestingly it becomes positive and statistically significant (at $\mathrm{p}<.10)$ when interacted with formal institutional void (in model 2) and with informal institutional void (in model 3).

However, it is worth observing that in order to better gauge the moderating role of the formal and informal institutional voids of a host country, it is necessary to calculate the marginal effects. Therefore,

\footnotetext{
12 See https://databox.worldbank.org/Extractives/Africa_PowerMining_Projects_Database/ez5p-5pcx; accessed on 11 June 2016.
} 
we estimate the marginal effects of FDI per capita on $\triangle$ Access to electricity through the following formula:

$\frac{\partial\left(\Delta \text { Access to electricity }_{\mathrm{i.t}}\right)}{\partial\left(\text { FDI per capita }_{\mathrm{i}, \mathrm{j}, \mathrm{t}-1}\right)} \mid=\beta_{1}+\beta_{4}$ (Formal Institutional Voids $\left._{i, t-1}\right)_{\max }+\beta_{5}$ (Informal Institutional Void $\left._{i}\right)_{\max }$

The baseline is a scenario where both types of institutions are working well. Coherently the overall moderating role of the two types of institutional void is simply the sum of the two individual moderating roles, because the model does not cross the variables for formal and informal institutional voids. The estimates of marginal effects are reported in Table 8, and they show that FDI stimulates the growth of the access to electricity of a local population when the host countries suffer from a double institutional void, i.e. when both formal and informal institutions are weak (the magnitude of the marginal effect is 0.02 , and it is significant at $\mathrm{p}<0.05$, for both the dimensions considered for informal institutions). This confirms our first hypothesis. In principle, MNEs' involvement could be driven by the presence of international sponsors such as development banks that mitigate the risk of private infrastructure projects in the region. Nonetheless, we tend to exclude that international development agencies play a major role in our results. In fact the relationship between FDI and access to electricity is moderated negatively by well-functioning formal institutions. By contrast, the typical contractual arrangements used by governments and development agencies to support the participation of private players in infrastructure investment require political, regulatory and judiciary protections (Moszoro et al., 2014).

[Insert Table 8 here]

Similarly, marginal effects are needed in order to interpret the findings obtained for the role of formal and informal institutional proximity, and their interactions with FDI per capita (Models 2-3, and Models 5-6 in Table 7). Namely, marginal effects come from the following formula:

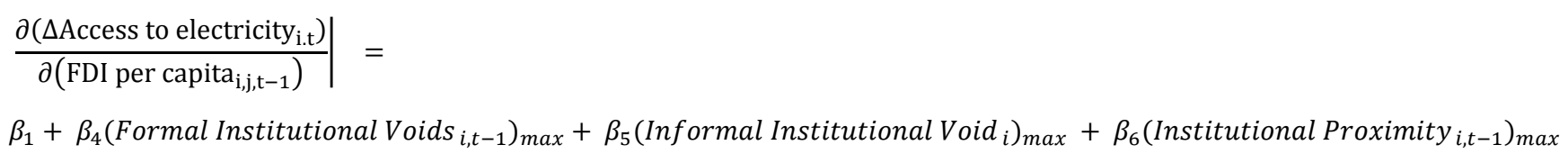

The results, reported in Table 8, show that FDI in host countries affected by both formal and informal institutional voids increase the access to electricity only if it comes from countries that present some degree of proximity with the host country, in terms of both formal institutions (the marginal effect is 0.02, significant at $\mathrm{p}<.10$ when informal institutions are proxied by the degree of 
collectivism/individualism, and 0.04, significant at $\mathrm{p}<.05$, when informal institutions are proxied by the degree of trust), and informal institutions (the marginal effect is 0.02, significant at $\mathrm{p}<.05$, and 70.95, significant at $\mathrm{p}<.05$, respectively). This confirms our second hypothesis. However, it may be also worth noting that, comparing the magnitude of marginal effects, it does appear that informal institutional proximity measured by trust is more important than proximity measured by similarity in terms of institutional collectivism.

Finally, in order to test the goodness of our results, we re-ran our models adopting alternative measures of the quality of informal institutions, namely Hofstede's individualism versus collectivism (Hofstede et al., 2010). ${ }^{13}$ This variable takes a high value when the society is considered individualist, which means that individuals are expected to only take care of themselves and their immediate families; conversely, the variable takes a low value when the society is collectivist, which means that individuals can expect their relatives or members of a particular group to look after them in exchange for unquestioning loyalty. The estimates and computed marginal effects are shown in Tables 9 and 10, respectively. The results are in line with those obtained with the other two dimensions of institutional voids, especially with the degree of institutional collectivism sourced from the GLOBE project.

[Insert Table 9 here]

[Insert Table 10 here]

\section{Discussion and conclusion}

This paper adds to the literature on the impact of FDI and MNEs on the host country development by focusing on a specific dimension of development, i.e. the access to electricity. Specifically, adopting institutional theory lens (North, 1990; Ostrom, 2000), we argue that as low rates of access to electricity stems mainly from the weakness of institutions, both formal and informal institutions should be taken into consideration. Within this context, we show that in a context of formal and informal institutional void, FDI can contribute to increase the access to electricity of the host country. In doing so, we consider the institutional framework of both the host and the home country, in accordance with the literature on the competitive advantage of foreign MNEs in developing countries (Cuervo-Cazurra and Genc, 2008; Kostova and Zaheer, 1999).

\footnotetext{
${ }^{13}$ As far as formal institutions are concerned, we rely on D'Amelio et al. (2016) where several checks have been conducted to investigate the robustness of their impacts.
} 
Our empirical analysis refers to SSA, and our findings, obtained with panel data techniques, reveal that FDI in countries affected by a double institutional void can effectively raise the access to electricity of the local populations. However, this happens when FDI come from countries that are institutionally closer to the host country (in both the formal and informal institutional environments). In particular, taking into account different dimensions of informal institutions, it emerges that FDI and the related MNEs coming from countries where the level of trust between individuals is low are particularly able to deal with the informal institutional void in the host country, thus having a greater impact on the electrification of the host country.

We believe these results provide some answers to stimuli put forward by Buckley and Boddewyn (2015) on the need of investigating how home institutional experience may be conducive to the positive assumption of societal functions abroad (Cuervo-Cazurra and Genc, 2008).

The paper also introduces important policy and managerial implications. As far as the former, our results suggest that FDI attraction polices should take into account both formal and informal institutional proximity between the host and the home country of the MNE. Indeed, these conditions seem to foster the energy development of host countries (thus paving the way to the long-term and inclusive development of the country). Our empirical evidence confirms previous claims about the role that MNEs can play in taking care of both market failures and institutional voids (a situation not uncommon in underdeveloped countries, where key economic, political, social and cultural institutions are either missing or defective), thus becoming economic and political actors that contribute to both private and public interests (Scherer et al., 2014). In fact, MNEs earn rents not only when markets do not function properly; they can also generate revenues when they assume the functions of missing or inefficient nonmarket institutions (Henisz, Doronbatu and Nartey, 2004; Buckley and Boddewyn, 2015.

Likewise, as far as managerial implications are concerned, those MNEs that are looking for legitimacy in developing countries should be aware of the role of institutional proximity when undertaking partnerships with local governments and/or local cooperatives and NGOs. In fact, in a recent paper on foreign MNEs during the pro-market reform of Uganda's electricity generation sector (Mbalyohere and Lawton, 2018) one of the most important determinants of MNE success in Africa is not only the in-depth comprehension of the political and socio-economic transformation, but also the capability to accurately predict the trends associated with these transformations. These capabilities had been developed especially by MNEs that were historically conversant with the African continent, but also by MNEs originating from countries sharing some institutional similarities with it. 
Our results also suggest to MNEs' managers what are those dimensions of informal institutions (e.g. trust) that might be more effective to gain legitimacy in a foreign country, in order to succeed in aligning their business considerations and their social engagement with societal benefits (Nachum, 2017).

As usual, the work is not immune from limitations that, however, could pave the way for future research. First of all, our econometric analysis has allowed us to assess the significance of the relationship between FDI, access to electricity, institutional voids, and institutional proximity. However, a qualitative in depth analysis would be needed to understand how the effects of institutions occur, i.e. to reveal the mechanisms, and the organizational and social processes through which MNEs and FDI improve access to electricity for the local population.

Second, although the results of our empirical analysis appear quite robust across several specifications, we had to deal with missing data through multiple imputation techniques in order to make the sample statistically acceptable, and with a measure of the presence of MNEs based on private investment, therefore underrepresenting State-owned enterprises and other governmental investors. This limits the possibility of generalizing our results to Chinese FDI in Africa that has insofar followed a model financial engagement mainly based on loans rather than investments ${ }^{14}$.

Overall, we believe that our conclusions are important, not only because we emphasize the role of informal institutions and the related informal institutionally proximity as moderating factors in the relationship between FDI and local development, but also in terms of their impact on research that focuses on emerging markets and under-researched "frontier markets", like those in Sub-Saharan Africa that may help shedding further light on the role of context in IB. In fact, we are only beginning to understand the contributions that studies of the African continent can bring to general management and IB research on the impact of business on society (Kolk and Rivera-Santos, 2018).

We discuss how FDI may foster access to energy in a local context, as a result of both market and nonmarket strategies. However, MNEs currently invest in developing countries for different reasons, from purely resource-seeking reasons to knowledge-seeking reasons, especially in search of bottom-of-thepyramid innovations (Chikhouni et al., 2017). These emerging motivations for internationalization may

\footnotetext{
${ }^{14}$ However, there are recent signals of a change in the model of financial engagement in Africa. Evolving away from the previous model, China has been increasingly keen on utilizing financing provided by Chinese development finance institutions, such as China Development Bank and China-Africa Development Fund, to support Chinese companies' equity investment in Africa. Nonetheless, and despite all the enthusiasm about China investing more in Africa, the actual volume of Chinese investment in African remains small, both in absolute terms and in comparison with other regions. In 2017, China's foreign direct investment toward Africa was $\$ 3.1$ billion, 2.5 percent of China's global foreign direct investment that year, the smallest among all continents (see https://www.brookings.edu/blog/africa-in-focus/2018/09/05/chinas-2018-financialcommitments-to-africa-adjustment-and-recalibration/).
} 
lead to a different balance between market and non-market strategies, and to a different involvement (and, consequently, impact) of MNEs within the local context. Additionally, investigating the impact of FDI on the provision of other collective and public goods (e.g. healthcare, education, and infrastructure) in developing countries could strengthen the generalizability of our results.

We believe that future research opportunities exist to investigate the role of MNEs in fostering local development, by adopting a firm-level analysis. In fact, while the novelty of the paper is that it integrates the study of the impact of FDI on the access to energy institutional distance, with the formal and informal institutions framework, we have adopted a country-level perspective. The motivations of MNEs underlying the specific FDI initiative may lead to different types of partnerships with local communities and NGOs and, consequently, a multi-level analysis could provide further hints on that (as recently suggested also by Kolk et al., 2018).

Finally, our results also add to the broader theme of the role of private sector investment in infrastructure and its pro-poor impacts (Shah and Batley, 2009) as we find that private sector participation has the potential to make the difference, contingent on a certain degree of institutional proximity between the home and the host country. This is in line with the framework recently suggested in Kolk et al (2018) that highlight the positive causal relationship between FDI and poverty reduction as well as the importance of factors that moderate this relationship, particularly industry and country effects. Among the latter, our results on "the governance characteristics" of the host countries, as well as their affinities with the home country of the FDI, certainly contribute to the needed research effort in this area. 


\section{References}

Abdouli, M., Hammami, S. (2017). Investigating the causality links between environmental quality, foreign direct investment and economic growth in MENA countries. International Business Review, 26(2), 264-278.

Adler, P. S., Kwon, S. W. (2002). Social capital: Prospects for a new concept. Academy of Management Review, 27(1), 17-40.

Ahlborg, H., Boräng, F., Jagers, S. C., Söderholm, P. (2015). Provision of electricity to African households: The importance of democracy and institutional quality. Energy Policy, 87, 125-135.

Allison, P. D. (2001). Missing data (Vol. 136). Thousand Oaks, CA: Sage publications.

Arellano, M., Bover, O. (1995). Another look at the instrumental variable estimation of error-components models. Journal of Econometrics, 68(1), 29-51.

Baltagi, B. H. (2005). Econometric Analysis of Data Panel. Volume 1. Hoboken, NJ: John Wiley and Sons.

Banerjee, S. G., Romo, Z., McMahon, G., Toledano, P., Robinson, P., Arroyo, I. P. (2014). The power of the mine: A transformative opportunity for sub-Saharan Africa. World Bank Publications.

Berry, H., Guillén, M. F., Zhou, N. (2010). An institutional approach to cross-national distance. Journal of International Business Studies, 41(9), 1460-1480.

Bergara, M. E., Henisz, W. J., Spiller, P. T. (1998). Political institutions and electric utility investment: A cross-nation analysis. California Management Review, 40(2), 18-35.

Beugelsdijk, S., Hennart J.-F., Slangen, A. Smeets, R. (2010), Why and how FDI stocks are a biased measure of MNE affiliate activity. Journal of International Business Studies 41(9): 1444-1459

Bigley, G. A., Pearce, J. L. (1998). Straining for shared meaning in organization science: Problems of trust and distrust. Academy of Management Review, 23(3), 405-421.

Blundell, R., Bond, S. (1998). Initial conditions and moment restrictions in dynamic panel data models. Journal of Econometrics, 87(1), 115-143.

Boettke, P. J., Coyne, C. J., Leeson, P. T. (2008). Institutional stickiness and the new development economics. American journal of economics and sociology, 67(2), 331-358.

Bond, S., Van Reenen, J. (2007). Microeconometric models of investment and employment. Handbook of econometrics, 6, 4417-4498.

Buckley, P. J., Boddewyn, J. J. (2015). The internalization of societal failures by multinational enterprises. The Multinational Business Review, 23(3), 170-187. 
Caves, R. E. (1974). Multinational Firms, Competition, and Productivity in Host-Country Markets. Economica, 41(162), 176-193.

Chikhouni A, Edwards G., Farashahi M. (2017), Psychic distance and ownership in acquisitions: Direction matters. Journal of International Management, 23: 32-42.

Cox, J. C., Ostrom, E., Walker, J. M., Castillo, A. J., Coleman, E., Holahan, R., Steed, B. (2009). Trust in private and common property experiments. Southern Economic Journal, 957-975.

Cuervo-Cazurra, A., Genc, M. (2008). Transforming disadvantages into advantages: developing-country MNEs in the least developed countries. Journal of International Business Studies, 39(6), 957-979.

D’Amelio, M., Garrone, P., Piscitello, L. (2016). Can multinational enterprises light up developing countries? Evidences from the access to electricity in sub-Saharan Africa. World Development, 88, 1232.

De Backer, K., Sleuwaegen, L. (2003). Does foreign direct investment crowd out domestic entrepreneurship?. Review of Industrial Organization, 22(1), 67-84.

De Beule F., Elia S., Piscitello L., (2014). Entry and access to competences abroad: Emerging market firms vs. advanced market firms. Journal of International Management, 20(2): 137-152.

DiMaggio, P. J., Powell, W. W. (1983). The iron cage revisited: Institutional isomorphism and collective rationality in organizational fields. American Sociological Review, 48(2), 147-160.

Dreher, A. (2006). Does globalization affect growth? Evidence from a new index of globalization. Applied Economics, 38(10), 1091-1110.

E\&Y. (2014). EY's Attractiveness Survey: Africa 2014. Ernest \& Young, UK.

Farla, K., De Crombrugghe, D., Verspagen, B. (2016). Institutions, foreign direct investment, and domestic investment: crowding out or crowding in? World Development, 88, 1-9.

Forsgren, M. (2017). Theories of the Multinational Firm. A Multidimensional Creature in the Global Economy. Third Edition. Edward Elgar: Cheltenham, UK.

Garrone, P., Grilli, L. 2010. Is there a relationship between public expenditures in energy R\&D and carbon emissions per GDP? An empirical investigation. Energy Policy, 38(10): 5600-5613.

Gillanders, R. (2014). Corruption and infrastructure at the country and regional level. Journal of Development Studies, 50(6), 803-819.

Haddad, M., Harrison, A. (1993). Are there positive spillovers from direct foreign investment? Evidence from panel data for Morocco. Journal of Development Economics, 42(1), 51-74.

Hansmann, H. (1996). The Ownership of Enterprise. The Belknap Press of Harvard University Press. 
Henisz, W. J. (2002). The institutional environment for infrastructure investment. Industrial and Corporate Change, 11(2), 355-389.

Henisz, W. J., Doronbatu S., Nartey, L. (2014). Spinning gold: The financial and operational returns to external stakeholder engagement, Strategic Management Journal, 35: 1727-1748.

Henisz, W. J., Zelner, B. A. (2001). The Institutional Environment for Telecommunications Investment. Journal of Economics \& Management Strategy, 10(1):123-148.

Hofstede, G., Hofstede, G. J., Minkov, M. (2010). Cultures et organisations: nos programmations mentales. Pearson Education France.

Holburn, G. L., Zelner, B. A. (2010). Political capabilities, policy risk, and international investment strategy: Evidence from the global electric power generation industry. Strategic Management Journal, 31(12), 1290-1315.

Holmes, R. M., Miller, T., Hitt, M. A., Salmador, M. P. (2013). The interrelationships among informal institutions, formal institutions, and inward foreign direct investment. Journal of Management, 39(2), 531-566.

Hübler, M., Keller, A. (2010). Energy savings via FDI? Empirical evidence from developing countries. Environment and Development Economics, 15(01), 59-80.

IEA. 2014. Africa Energy Outlook. A focus of Energy Prospects in sub-Saharan Africa. Fostering Durable and Inclusive Growth. International Energy Agency, Paris.

Kaul, I. (2001). Public Goods in the 21st Century. In Global Public Goods: Taking the Concept Forward. Discussion Paper 17. New York: United Nations Development Programme, Office of Development Studies.

Kaul I., Mendoza R.U. (2003). Advancing the Concept of Public Goods’, in Inge Kaul, Pedro Conceição, Katell Le Goulven and Ronald U. Mendoza (eds), Providing Global Public Goods: Managing Globalization, Part 1, New York, NY, USA, Oxford, UK: Oxford University Press, 78-111

Khanna, T., Palepu, K. (1997). Why focused strategies may be wrong for emerging markets. Harvard Business Review, 75(4), 41-48.

Kolk A., Rivera-Santos M. (2018). The State of Research on Africa in Business and Management: Insights From a Systematic Review of Key International Journals, Business \& Society, 57(3): 415-436. Kolk A., Rivera-Santos M., Rufin C. (2018). Multinationals, international business, and poverty: A crossdisciplinary research overview and conceptual framework. Journal of International Business Policy, 1(12): $92-115$. 
Kostova, T., Zaheer, S. (1999). Organizational legitimacy under conditions of complexity: The case of the multinational enterprise. Academy of Management Review, 24(1), 64-81.

Levy, B., Spiller, P. T. (1994). The Institutional Foundations of Regulatory Commitment: A Comparative Analysis of Telecommunications Regulation. Journal of Law, Economics, \& Organization, 10(2), 201246.

London, T., Hart, S.L. (2004), Reinventing strategies for emerging markets: beyond the transnational model. Journal of International Business Studies, 35(5), 350-370.

Mbalyohere, C., Lawton, T.C. (2018). Engaging Stakeholders Through Corporate Political Activity: Insights From MNE Nonmarket Strategy in an Emerging African Market. Journal of International Management, forthcoming, https://doi.org/10.1016/j.intman.2018.04.006.

Mbalyohere, C., Lawton, T.C., Boojihawon, R., Viney, H. (2017). Corporate political activity and location-based advantage: MNE responses to institutional transformation in Uganda's electricity industry. Journal of World Business, 52(6): 743-759.

Moszoro, M. W., Araya, G., Ruiz Nunez, F., Schwartz, J. (2014). Institutional and political determinants of private participation in infrastructure. No. 2014/15, OECD Publishing, Paris, http://dx.doi.org/10.1787/5jrw2xzj0m71-en.

Nachum, L. (2017). How much social responsibility should firms assume and of which kind? Firms, governments and NGOs as alternative providers of social services. Columbia FDI Perspectives. Perspectives on topical foreign direct investment issues, No. 207, August 28.

North, D. C. (1990). Institutions, institutional change and economic performance. Cambridge University Press.

Ostrom, E. 1990. Governing the Commons: the evolution of institutions for collective action. Cambridge: Cambridge University Press.

Ostrom, E., Schroeder, L., Wynne, S. (1993). Institutional incentives and sustainable development: Infrastructure policies in perspective. Westview Press, Inc.

Ostrom E. (2000). Collective Action and the Evolution of Social Norms. Journal of Economic Perspectives, 14(3), 137-158,

Oetzel, J., Doh, J. P. (2009). MNEs and Development: a Review and Reconceptualization. Journal of World Business, 44(2), 108-120. 
Robbins, G., Perkins, D. (2012). Mining FDI and infrastructure development on Africa's East Coast: examining the recent experience of Tanzania and Mozambique. Journal of International Development, 24(2), 220-236.

Rottig, D. (2016). Institutions and emerging markets: effects and implications for multinational corporations. International Journal of Emerging Markets, 11(1), 2-17.

Sesan, T., Raman, S., Clifford, M., Forbes, I. (2013). Corporate-led sustainable development and energy poverty alleviation at the bottom of the pyramid: The case of the CleanCook in Nigeria. World Development, 45, 137-146.

Shah, R. and Batley, R. (2009), Private-Sector Investment in Infrastructure: Rationale and Causality for Pro-poor Impacts. Development Policy Review, 27(4): 397-417.

Scherer A.G., Palazzo G., Matten D. (2014), Global rules and private actors: Toward a new role for the transnational corporation in global governance. Business Ethics Quarterly, 16(4): 505-532.

Sovacool, B. K. (2012). The political economy of energy poverty: A review of key challenges. Energy for Sustainable Development, 16(3), 272-282.

Spiller, P. T. (2013). Transaction cost regulation. Journal of Economic Behavior \& Organization, 89, 232-242.

Teece, D. J. (1977). Technology Transfer by Multinational Firms: The resource cost of transferring technological know-how. The Economic Journal, 87(346), 242-261.

Teegen, H. (2003). International NGOs as global institutions: Using social capital to impact multinational enterprises and governments. Journal of International Management, 9(3), 271-285.

WB. (2015). Global Economic Prospects June 2015. World Bank, Washington DC.

Toledano, P. (2012). Leveraging the mining industry's energy demand to improve host countries' power infrastructure. CCSI Policy Paper, The Columbia Center on Sustainable Investment (CCSI).

Windmeijer, F. (2005). A finite sample correction for the variance of linear efficient two-step GMM estimators. Journal of Econometrics, 126(1), 25-51.

Zaheer, S. (1995). Overcoming the liability of foreignness. Academy of Management Journal, 38(2), 341-363. 


\section{Tables}

Table 1. Options for electricity provision in developing countries under different combinations of formal and informal institutions, and distribution of the sample of Sub-Saharan Africa countries

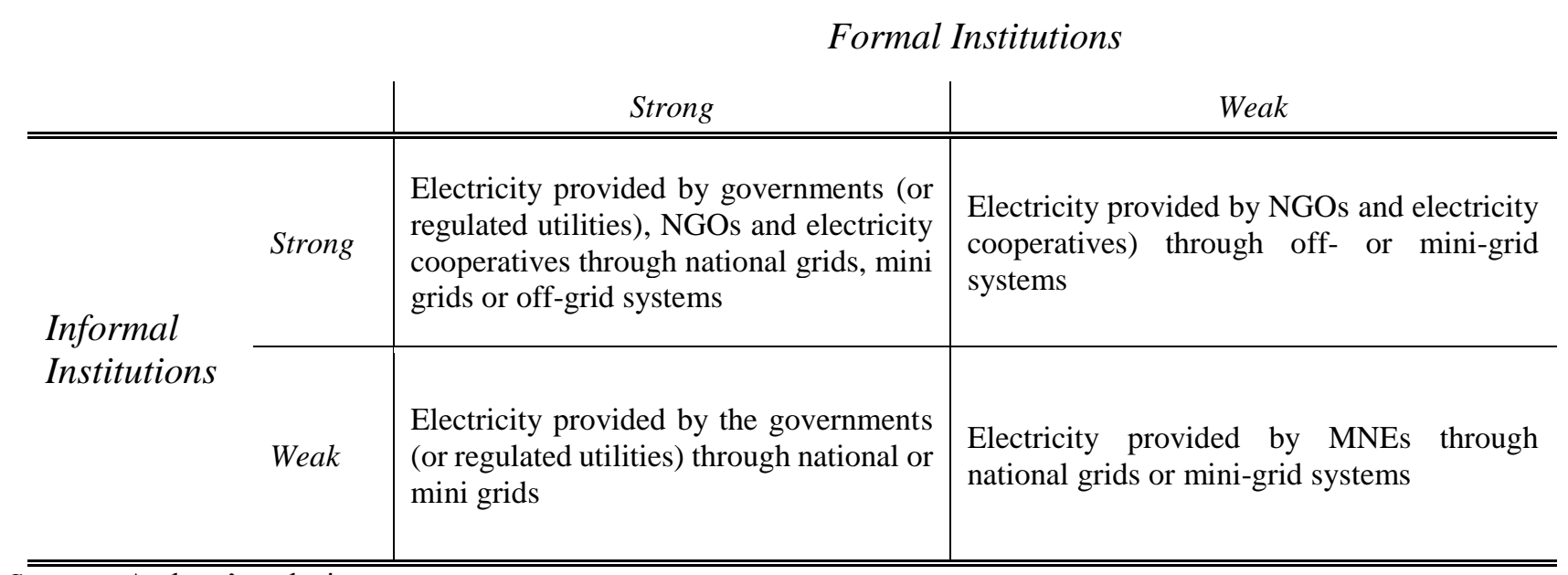

Sources: Authors' analysis.

Note: Our sample covers 15 Sub-Saharan Africa countries that distribute across the 4 table cells, i.e. 3, 4, 2 and 6 countries are placed respectively in the Strong Informal - Strong Formal, Strong Informal - Weak Formal, Weak Informal - Strong Formal, Weak Informal - Weak Formal cells. 
Table 2. Home and host country pairs in our dataset.

\begin{tabular}{|c|c|c|c|}
\hline \multicolumn{3}{|c|}{ Home countries } & \multirow{2}{*}{$\begin{array}{l}\text { Host countries } \\
\text { South Africa }\end{array}$} \\
\hline Angola & Israel & Saudi Arabia & \\
\hline Argentina & Italy & Seychelles & Ghana \\
\hline Aruba & Japan & Singapore & Mauritius \\
\hline Australia & Kenya & Slovenia & Angola \\
\hline Austria & Korea, Rep. & South Africa & Cameroon \\
\hline Bahamas, The & Lebanon & Spain & Congo, Rep. \\
\hline Bahrain & Liberia & Sri Lanka & Congo, Dem. Rep. \\
\hline Belgium & Libya & Swaziland & Gabon \\
\hline Bermuda & Liechtenstein & Sweden & Kenya \\
\hline Botswana & Luxembourg & Switzerland & Uganda \\
\hline Brazil & Madagascar & Taiwan, China & Eritrea \\
\hline Bulgaria & Malawi & Tanzania & Ethiopia \\
\hline Canada & Malaysia & Thailand & Botswana \\
\hline Cayman Islands & Maldives & Togo & Namibia \\
\hline China & Malta & Turkey & Nigeria \\
\hline Cote d'Ivoire & Mauritius & United Kingdom & \\
\hline Cyprus & Morocco & United States & \\
\hline Czech Republic & Mozambique & Uganda & \\
\hline Denmark & Namibia & United Arab Emirates & \\
\hline Finland & Netherlands & Uruguay & \\
\hline France & New Zealand & Yemen, Rep. & \\
\hline Germany & Nigeria & Zambia & \\
\hline Ghana & Norway & Zimbabwe & \\
\hline Greece & Pakistan & & \\
\hline Hong Kong SAR, China & Panama & & \\
\hline Hungary & Paraguay & & \\
\hline Iceland & Philippines & & \\
\hline India & Poland & & \\
\hline Indonesia & Portugal & & \\
\hline Ireland & Russian Feder & & \\
\hline
\end{tabular}

Source: Sample data from UNCTAD FDI Statistics Division on Investment and Enterprise

(http://unctadstat.unctad.org/wds/ReportFolders/reportFolders.aspx) accessed on 15th June 2015. 
Table 3. Access to electricity rate in Sub-Saharan African host countries, 2005 and 2011.

\begin{tabular}{lcc}
\hline & 2005 & 2011 \\
\hline & $\begin{array}{c}\text { (Households) } \\
\text { access to electricity } \\
(\%)\end{array}$ & 67 \\
\hline Sub-Saharan Africa & 53 & 38 \\
\hline Angola & 15 & 46 \\
Botswana & 39 & 54 \\
Cameroon & 47 & 9 \\
Congo, Dem. Rep. & 6 & 37 \\
Congo, Rep. & 20 & 32 \\
Eritrea & 20 & 23 \\
Ethiopia & 15 & 60 \\
Gabon & 48 & 72 \\
Ghana & 49 & 19 \\
Kenya & 14 & 99 \\
Mauritius & 94 & 60 \\
Namibia & 34 & 48 \\
Nigeria & 46 & 85 \\
South Africa & 70 & 15 \\
Uganda & 9 & \\
\hline Source: Sample data from International Energy Agency (http://www.worldenergyoutlook.org/resources/energydevelopment/energyaccessdatabase/) \\
accessed on 24th May 2016 and authors' calculation.
\end{tabular}


Table 4. Distribution of FDI per capita by region of origin.

\begin{tabular}{lcc}
\hline \hline & $\begin{array}{c}\text { FDI per capita } \\
\text { (US dollar) }\end{array}$ & $\%$ \\
\hline China (w/ Hong Kong) & & \\
East Asia (w/o China \& Hong Kong) & 18,684 & 6.60 \\
European Union & 4,222 & 1.50 \\
India & 80,385 & 28.60 \\
Latin America \& Caribbean of Origin & 7,916 & 2.80 \\
North Africa \& Middle East & 20,713 & 7.40 \\
North America & 6,541 & 2.30 \\
Oceania & 55,250 & 19.60 \\
Russia & 12,014 & 4.30 \\
South East Asia & 153 & 0.10 \\
South Asia (w/o India) & 42,543 & 15.10 \\
Sub-Saharan Africa & 1,921 & 0.70 \\
Total & 30,923 & 11.00 \\
\hline \hline
\end{tabular}

Source: Sample data from UNCTAD FDI Statistics Division on Investment and Enterprise

(http://unctadstat.unctad.org/wds/ReportFolders/reportFolders.aspx) accessed on 15th March 2015 and authors' calculation. 
Table 5. Formal institutional voids: loadings from the factor analysis

\begin{tabular}{|l|c|c|}
\hline \multicolumn{1}{|c|}{$\begin{array}{c}\text { World Bank Governance } \\
\text { Indicators }\end{array}$} & Institutional quality host & Institutional quality home \\
\hline Political stability & 0.8230 & 0.9449 \\
\hline Rule of law & 0.9615 & 0.9554 \\
\hline Voice and Accountability & 0.9467 & 0.9502 \\
\hline Control of Corruption & 0.9338 & 0.8468 \\
\hline Governance Effectiveness & 0.9644 & 0.9628 \\
\hline Regulatory Quality & 0.9357 & 0.8520 \\
\hline $\begin{array}{l}\text { Cumulative proportion of WGIs } \\
\text { variance explained by the factor }\end{array}$ & $86.26 \%$ & $84.64 \%$ \\
\hline
\end{tabular}

Note: $\mathrm{N}=1547$ 
Table 6. Sample variables: descriptive statistics and correlation matrix ( $\mathrm{N}=1547)$.

\begin{tabular}{|c|c|c|c|c|c|c|c|c|c|c|c|c|c|c|c|c|c|c|c|c|c|c|}
\hline & Variable & Mean & $\begin{array}{l}\text { Std. } \\
\text { Dev. }\end{array}$ & Min & Max & (1) & (2) & (3) & (4) & (5) & (6) & (7) & (8) & (9) & (10) & (11) & (12) & (13) & (14) & (15) & $(16)$ & (17) \\
\hline (1) & Access to electricity & 58.91 & 28.07 & 5.80 & 99.00 & 1 & & & & & & & & & & & & & & & & \\
\hline (2) & Population & 29.21 & 24.55 & 1.20 & 160.00 & $-0.12^{*}$ & 1 & & & & & & & & & & & & & & & \\
\hline (3) & Rural population & 50.72 & 16.46 & 13.85 & 86.75 & $-0.42 *$ & 0.02 & 1 & & & & & & & & & & & & & & \\
\hline (4) & Population density & 170.76 & 205.00 & 2.46 & 633.52 & $0.62 *$ & $-0.47 *$ & $0.17 *$ & 1 & & & & & & & & & & & & & \\
\hline (5) & Industry value added & 32.79 & 13.74 & 10.39 & 77.41 & $-0.16^{*}$ & $-0.27 *$ & $-0.49 *$ & $-0.28^{*}$ & 1 & & & & & & & & & & & & \\
\hline (6) & Services value added & 55.23 & 14.12 & 18.91 & 70.94 & $0.63 *$ & $0.12 *$ & -0.02 & $0.40^{*}$ & $-0.60^{*}$ & 1 & & & & & & & & & & & \\
\hline (7) & LIC & 0.28 & 0.45 & 0.00 & 1.00 & $-0.59 *$ & $0.21 *$ & $0.65^{*}$ & $-0.17^{*}$ & $-0.42^{*}$ & $-0.29 *$ & 1 & & & & & & & & & & \\
\hline (8) & LMIC & 0.13 & 0.34 & 0.00 & 1.00 & $-0.22^{*}$ & $-0.22^{*}$ & $-0.11 *$ & $-0.19^{*}$ & $0.50^{*}$ & $-0.54 *$ & $-0.24 *$ & 1 & & & & & & & & & \\
\hline (9) & FDI per capita & 181.81 & 1496.38 & 0.04 & 39379.23 & $0.11 *$ & $-0.12^{*}$ & 0.02 & $0.17 *$ & -0.02 & $0.07 *$ & $-0.07 *$ & -0.01 & 1 & & & & & & & & \\
\hline (10) & Formal institutional voids & 1.27 & 1.00 & 0.00 & 3.76 & $-0.78 *$ & $0.19^{*}$ & $0.26^{*}$ & $-0.57 *$ & $0.34 *$ & $-0.76^{*}$ & $0.46^{*}$ & $0.44 *$ & $-0.10^{*}$ & 1 & & & & & & & \\
\hline (11) & $\begin{array}{l}\text { Informal institutional voids } \\
\text { (Hofstede) }\end{array}$ & 38.67 & 21.12 & 15.00 & 65.00 & $0.34 *$ & $0.39 *$ & $-0.45 *$ & $-0.26^{*}$ & -0.03 & $0.56^{*}$ & $-0.52^{*}$ & $-0.35^{*}$ & $-0.05^{*}$ & $-0.51 *$ & 1 & & & & & & \\
\hline (12) & $\begin{array}{l}\text { Informal institutional voids } \\
\text { (individualism) }\end{array}$ & 0.53 & 0.30 & 0.00 & 0.85 & $0.15^{*}$ & $0.26^{*}$ & $-0.57 *$ & $-0.44 *$ & $0.38^{*}$ & $0.20^{*}$ & $-0.67^{*}$ & $0.05^{*}$ & $-0.05^{*}$ & $-0.11 *$ & $0.79 *$ & 1 & & & & & \\
\hline (13) & $\begin{array}{l}\text { Informal institutional voids } \\
\text { (distrust) }\end{array}$ & 1200.54 & 1087.68 & 0.00 & 2529.00 & $-0.17^{*}$ & $-0.34 *$ & $0.62^{*}$ & $0.45 *$ & $-0.27 *$ & $-0.20^{*}$ & $0.56^{*}$ & 0.03 & $0.07 *$ & $0.24 *$ & $-0.83^{*}$ & $-0.83^{*}$ & 1 & & & & \\
\hline (14) & Formal institutional proximity & 6.57 & 1.47 & 0.00 & 8.57 & $0.21 *$ & $0.11^{*}$ & $-0.13 *$ & -0.03 & $-0.21 *$ & $0.23^{*}$ & $-0.05^{*}$ & $-0.17 *$ & -0.02 & $-0.32 *$ & $0.23 *$ & $0.05 *$ & $-0.15^{*}$ & 1 & & & \\
\hline (15) & $\begin{array}{l}\text { Informal institutional proximity } \\
\text { (Hofstede) }\end{array}$ & 2.75 & 0.92 & 0.00 & 4.45 & $-0.04 *$ & $-0.19^{*}$ & $0.30 *$ & $0.24 *$ & -0.04 & -0.03 & $0.07 *$ & $0.06^{*}$ & 0.02 & $0.07 *$ & $-0.31^{*}$ & $-0.24 *$ & $0.35^{*}$ & -0.03 & 1 & & \\
\hline (16) & $\begin{array}{l}\text { Informal institutional proximity } \\
\text { (individualism) }\end{array}$ & 4.88 & 1.36 & 0.00 & 6.71 & $-0.12 *$ & $-0.22 *$ & $0.09 *$ & -0.02 & $0.21^{*}$ & -0.03 & $-0.21^{*}$ & $0.10^{*}$ & $0.07 *$ & $0.11^{*}$ & 0.01 & $0.21^{*}$ & $0.07 *$ & $-0.28^{*}$ & $0.11^{*}$ & 1 & \\
\hline (17) & $\begin{array}{l}\text { Informal institutional proximity } \\
\text { (distrust) }\end{array}$ & 8.47 & 2.00 & 0.00 & 9.96 & 0.03 & 0.01 & -0.04 & $0.06 *$ & 0.01 & $-0.12^{*}$ & $0.06^{*}$ & $0.06 *$ & -0.03 & $0.10^{*}$ & $-0.16^{*}$ & $-0.11 *$ & $0.15^{*}$ & $-0.11^{*}$ & $-0.13^{*}$ & $-0.09 *$ & 1 \\
\hline
\end{tabular}

Source: Authors' calculation. ${ }^{*} \mathrm{p}<0.10$. 
Table 7. System GMM Estimates.

\begin{tabular}{|c|c|c|c|c|c|c|}
\hline & \multirow{2}{*}{\multicolumn{3}{|c|}{ Informal Institutional Void: Degree of Individualism }} & \multirow{2}{*}{\multicolumn{3}{|c|}{ Informal Institutional Void: Degree of Distrust }} \\
\hline & & & & & & \\
\hline VARIABLES & $\begin{array}{c}(1) \\
\text { Host Formal and } \\
\text { Informal Institutional } \\
\text { Void } \\
\end{array}$ & $\begin{array}{c}(2) \\
\text { Formal Institutional } \\
\text { Proximity } \\
\end{array}$ & $\begin{array}{c}(3) \\
\text { Informal } \\
\text { Institutional } \\
\text { Proximity } \\
\end{array}$ & $\begin{array}{c}(4) \\
\text { Host Formal and } \\
\text { Informal Institutional } \\
\text { Void } \\
\end{array}$ & $\begin{array}{c}\text { (5) } \\
\text { Formal Institutional } \\
\text { Proximity } \\
\end{array}$ & $\begin{array}{c}6) \\
\text { Informal } \\
\text { Institutional } \\
\text { Proximity } \\
\end{array}$ \\
\hline Access to electricity $\mathrm{t}-1$ & $\begin{array}{c}-0.70 * * * \\
(0.06)\end{array}$ & $\begin{array}{c}-0.65^{* * * *} \\
(0.06)\end{array}$ & $\begin{array}{c}-0.67 * * * * \\
(0.06)\end{array}$ & $\begin{array}{c}-0.67 * * * \\
(0.06)\end{array}$ & $\begin{array}{c}-0.65^{\text {**** }} \\
(0.06)\end{array}$ & $\begin{array}{c}-0.73 * * * \\
(0.07)\end{array}$ \\
\hline Population t-1 & $\begin{array}{c}0.16 * * * \\
(0.03)\end{array}$ & $\begin{array}{c}0.16 * * * \\
(0.03)\end{array}$ & $\begin{array}{c}0.09 * * * \\
(0.03)\end{array}$ & $\begin{array}{c}0.14 * * * \\
(0.03)\end{array}$ & $\begin{array}{c}0.13 * * * \\
(0.03)\end{array}$ & $\begin{array}{l}0.14 * * * \\
(0.03)\end{array}$ \\
\hline Rural population t-1 & $\begin{array}{c}-0.39^{* * * *} \\
(0.08)\end{array}$ & $\begin{array}{c}-0.37 * * * \\
(0.08)\end{array}$ & $\begin{array}{c}-0.25^{* * * *} \\
(0.08)\end{array}$ & $\begin{array}{c}-0.47^{* * * *} \\
(0.08)\end{array}$ & $\begin{array}{c}-0.45^{* * * *} \\
(0.08)\end{array}$ & $\begin{array}{c}-0.55^{* * * *} \\
(0.09)\end{array}$ \\
\hline Population density $\mathrm{t}-1$ & $\begin{array}{c}0.04 * * * \\
(0.01)\end{array}$ & $\begin{array}{c}0.033 * * * \\
(0.01)\end{array}$ & $\begin{array}{c}0.03^{* * *} \\
(0.01)\end{array}$ & $\begin{array}{c}0.05 * * * \\
(0.01)\end{array}$ & $\begin{array}{c}0.05 * * * \\
(0.01)\end{array}$ & $\begin{array}{l}0.05^{* * * *} \\
(0.01)\end{array}$ \\
\hline Industry value added $\mathrm{t}-1$ & $\begin{array}{l}-0.14 \\
(0.11)\end{array}$ & $\begin{array}{l}-0.14 \\
(0.11)\end{array}$ & $\begin{array}{l}-0.09 \\
(0.11)\end{array}$ & $\begin{array}{l}-0.01 \\
(0.08)\end{array}$ & $\begin{array}{l}-0.01 \\
(0.08)\end{array}$ & $\begin{array}{c}0.07 \\
(0.09)\end{array}$ \\
\hline Services value added $t-1$ & $\begin{array}{c}0.34 * * * \\
(0.1)\end{array}$ & $\begin{array}{c}0.22 * * \\
(0.1)\end{array}$ & $\begin{array}{c}0.34 * * * \\
(0.11)\end{array}$ & $\begin{array}{c}0.30 * * * \\
(0.08)\end{array}$ & $\begin{array}{c}0.29 * * * \\
(0.08)\end{array}$ & $\begin{array}{c}0.54 * * * \\
(0.09)\end{array}$ \\
\hline LMIC & $\begin{array}{l}-4.45^{*} \\
(2.61)\end{array}$ & $\begin{array}{l}-4.1 \\
(2.53)\end{array}$ & $\begin{array}{c}-8.13 * * * * \\
(2.59)\end{array}$ & $\begin{array}{l}5.62 * * * \\
(1.62)\end{array}$ & $\begin{array}{c}5.64 * * * \\
(1.64)\end{array}$ & $\begin{array}{l}7.80 * * * \\
(1.88)\end{array}$ \\
\hline LIC & $\begin{array}{c}-24.55^{* * *} \\
(4.37)\end{array}$ & $\begin{array}{c}-21.32 * * * \\
(4.09)\end{array}$ & $\begin{array}{c}-27.89 * * * \\
(4.08)\end{array}$ & - & - & - \\
\hline FDI per capita t-1 & $\begin{array}{c}-0.02^{* *} \\
(0.02)\end{array}$ & $\begin{array}{l}-0.03 \\
(0.03)\end{array}$ & $\begin{array}{c}0.04 \\
(0.04)\end{array}$ & $\begin{array}{l}-0.004 \\
(0.004)\end{array}$ & $\begin{array}{l}-0.05 \\
(0.04)\end{array}$ & $\begin{array}{l}-0.003 \\
(0.004)\end{array}$ \\
\hline Formal institutional void t-1 & $\begin{array}{c}0.08 \\
(1.33)\end{array}$ & $\begin{array}{l}-1.34 \\
(1.15)\end{array}$ & $\begin{array}{l}1.01 \\
(1.51)\end{array}$ & $\begin{array}{c}-3.50^{* * * *} \\
(1.18)\end{array}$ & $\begin{array}{l}-3.96^{* * * *} \\
(1.26)\end{array}$ & $\begin{array}{l}-2.92 * * \\
(1.27)\end{array}$ \\
\hline Informal institutional void & $\begin{array}{c}-20.22^{* * * *} \\
(5.61)\end{array}$ & $\begin{array}{c}-16.90 * * * \\
(5.02)\end{array}$ & $\begin{array}{c}-16.67 * * * \\
(5.37)\end{array}$ & $\begin{array}{l}-0.001 \\
(0.001)\end{array}$ & $\begin{array}{l}-0.001 \\
(0.001)\end{array}$ & $\begin{array}{c}0.001 \\
(0.001)\end{array}$ \\
\hline FDI per capita $\mathrm{t}-1 *$ Formal institutional void $\mathrm{t}-1$ & $\begin{array}{c}0.003 \\
(0.003)\end{array}$ & $\begin{array}{c}0.01 * \\
(0.004)\end{array}$ & $\begin{array}{l}0.01^{*} \\
(0.01)\end{array}$ & $\begin{array}{c}0.01 * \\
(0.003)\end{array}$ & $\begin{array}{l}0.01 * * \\
(0.003)\end{array}$ & $\begin{array}{c}0.01 \\
(0.004)\end{array}$ \\
\hline FDI per capita $\mathrm{t}-1 *$ Informal institutional void & $\begin{array}{c}0.02 * * \\
(0.01)\end{array}$ & $\begin{array}{c}-0.02 \\
(0.02)\end{array}$ & $\begin{array}{l}-0.01 \\
(0.02)\end{array}$ & $\begin{array}{c}0.001 \\
(0.001)\end{array}$ & $\begin{array}{c}0.001 \\
(0.001)\end{array}$ & $\begin{array}{l}-0.001 \\
(0.001)\end{array}$ \\
\hline Formal institutional proximity $\mathrm{t}-1$ & - & $\begin{array}{l}-0.02 \\
(0.4)\end{array}$ & - & - & $\begin{array}{l}-0.09 \\
(0.4)\end{array}$ & - \\
\hline FDI per capita $\mathrm{t}-1 *$ Formal institutional proximity $\mathrm{t}-1$ & - & $\begin{array}{c}0.01 \\
(0.01)\end{array}$ & - & - & $\begin{array}{c}0.01 \\
(0.01)\end{array}$ & - \\
\hline Informal institutional proximity & - & - & $\begin{array}{c}-3.58^{* * * *} \\
(0.96)\end{array}$ & - & - & $\begin{array}{c}0.04 \\
(0.23)\end{array}$ \\
\hline FDI per capita t- $1 *$ Informal institutional proximity & - & - & $\begin{array}{l}-0.01 \\
(0.01)\end{array}$ & - & - & $\begin{array}{l}0.001 * * \\
(0.001)\end{array}$ \\
\hline Constant & $\begin{array}{c}56.02 * * * * \\
(9.33)\end{array}$ & $\begin{array}{c}55.72 * * * * \\
(10.14)\end{array}$ & $\begin{array}{c}61.58^{* * * *} \\
(8.75)\end{array}$ & $\begin{array}{c}37.76 * * * \\
(7.88)\end{array}$ & $\begin{array}{c}38.34 * * * * \\
(8.77)\end{array}$ & $\begin{array}{c}30.34 * * * \\
(8.74)\end{array}$ \\
\hline Observations & 1,326 & 1,326 & 1,326 & 1,326 & 1,326 & 1,105 \\
\hline Number of pair countries & 221 & 221 & 221 & 221 & 221 & 221 \\
\hline $\mathrm{AR}(1)$ & -5.64 & -5.58 & -5.72 & -5.51 & -5.57 & -5.012 \\
\hline $\operatorname{AR}(2)$ & 0.63 & 1.1 & 0.63 & 1.2 & 1.23 & 0.46 \\
\hline Wald test & 220.39 & 220.71 & 216.59 & 221 & 220.91 & 218.81 \\
\hline
\end{tabular}

Source: Authors' calculation. Notes: Dependent variable $\Delta$ Access to electricity. Two-step system-GMM. Robust standard errors in parentheses. All AR(I) test statistics statistically
statistically insignificant. All Hansen test statistics statistically insignificant. ${ }^{* *}$ Significant at 1 per cent level. $* *$ Significant at 5 per cent level. * Significant at 10 per cent level. 


\section{Table 8. Access to electricity growth: Marginal effects of FDI per capita.}

\begin{tabular}{|c|c|c|c|}
\hline & \multirow[b]{2}{*}{$\begin{array}{l}\text { Informal Institutional } \\
\text { Voids: Degree of } \\
\text { Individualism }\end{array}$} & \multirow[b]{2}{*}{$\begin{array}{l}\text { Informal Institutional Voids: } \\
\text { Degree of Distrust }\end{array}$} \\
\hline & & & \\
\hline \multirow{2}{*}{\multicolumn{2}{|c|}{$\begin{array}{l}\text { Host Formal and Informal Institutional Void } \\
\text { (H1) }\end{array}$}} & $0.02 *$ & $0.02 *$ \\
\hline & & $(0.01)$ & $(0.11)$ \\
\hline \multirow{4}{*}{$\begin{array}{l}\text { Host Formal and Informal } \\
\text { Institutional Voids } \\
\text { (H2) }\end{array}$} & Formal Institutional Proximity & $0.02 *$ & $0.04 * *$ \\
\hline & & $(0.01)$ & $(0.02)$ \\
\hline & Formal Institutional Distance & -0.02 & -0.02 \\
\hline & гоminal misticutional Distance & $(0.03)$ & $(0.03)$ \\
\hline \multirow{4}{*}{$\begin{array}{l}\text { Host Formal and Informal } \\
\text { Institutional Voids } \\
\text { (H2) }\end{array}$} & Informal Inctitutional Proximity & $0.02 * *$ & $70.95^{* *}$ \\
\hline & Intormal institutional Proximity & $(0.01)$ & (32.08) \\
\hline & Informal Institutional Distance & 0.07 & 0.01 \\
\hline & & $(0.04)$ & $(0.01)$ \\
\hline
\end{tabular}

Two-step system GMM. Robust standard errors in parentheses.

*** Significant at 1 per cent level. ** Significant at 5 per cent level. * Significant at 10 per cent level. 
Table 9. Alternative measure of quality of informal institutions: System GMM Estimates

\begin{tabular}{|c|c|c|c|}
\hline VARIABLES & $\begin{array}{c}\text { (1) } \\
\text { Host Formal and } \\
\text { Informal } \\
\text { Institutional Void }\end{array}$ & $\begin{array}{c}(2) \\
\text { Formal } \\
\text { Institutional } \\
\text { Proximity }\end{array}$ & $\begin{array}{c}\text { (3) } \\
\text { Informal } \\
\text { Institutional } \\
\text { Proximity }\end{array}$ \\
\hline Access to electricity t-1 & $\begin{array}{c}-0.71 * * * \\
(0.05)\end{array}$ & $\begin{array}{c}-0.79 * * * \\
(0.06)\end{array}$ & $\begin{array}{c}-0.71 * * * \\
(0.05)\end{array}$ \\
\hline Population t-1 & $\begin{array}{c}0.17 * * * \\
(0.03)\end{array}$ & $\begin{array}{c}0.20 * * * \\
(0.04)\end{array}$ & $\begin{array}{c}0.17 * * * \\
(0.03)\end{array}$ \\
\hline Rural population $\mathrm{t}-1$ & $\begin{array}{c}-0.39 * * * \\
(0.07)\end{array}$ & $\begin{array}{c}-0.45 * * * \\
(0.08)\end{array}$ & $\begin{array}{c}-0.39 * * * \\
(0.08)\end{array}$ \\
\hline Population density t-1 & $\begin{array}{c}0.04^{* * * *} \\
(0.01)\end{array}$ & $\begin{array}{c}0.04 * * * \\
(0.01)\end{array}$ & $\begin{array}{c}0.04 * * * \\
(0.01)\end{array}$ \\
\hline Industry value added $\mathrm{t}-1$ & $\begin{array}{c}-0.22 * * \\
(0.11)\end{array}$ & $\begin{array}{l}-0.04 \\
(0.13)\end{array}$ & $\begin{array}{c}-0.22 * * \\
(0.10)\end{array}$ \\
\hline Services value added $\mathrm{t}-1$ & $\begin{array}{l}0.18^{*} \\
(0.10)\end{array}$ & $\begin{array}{c}0.45^{* * *} \\
(0.12)\end{array}$ & $\begin{array}{l}0.17^{*} \\
(0.10)\end{array}$ \\
\hline LMIC & $\begin{array}{l}-3.89 \\
(2.46)\end{array}$ & $\begin{array}{l}-2.14 \\
(3.08)\end{array}$ & $\begin{array}{l}-3.84 \\
(2.42)\end{array}$ \\
\hline LIC & $\begin{array}{c}-18.27 * * * \\
(3.51)\end{array}$ & $\begin{array}{c}-16.96^{* * * *} \\
(4.15)\end{array}$ & $\begin{array}{c}-18.08 * * * \\
(3.49)\end{array}$ \\
\hline FDI per capita $\mathrm{t}-1$ & $\begin{array}{l}-0.01 \\
(0.01)\end{array}$ & $\begin{array}{l}-0.02 \\
(0.02)\end{array}$ & $\begin{array}{l}0.001 \\
(0.01)\end{array}$ \\
\hline Formal institutional voids $\mathrm{t}-1$ & $\begin{array}{c}-4.24 * * * \\
(1.45)\end{array}$ & $\begin{array}{c}-4.37 * * * \\
(1.64)\end{array}$ & $\begin{array}{c}-4.16 * * * \\
(1.44)\end{array}$ \\
\hline Informal institutional void & $\begin{array}{c}-0.20 * * \\
(0.09)\end{array}$ & $\begin{array}{c}-0.27 * * * \\
(0.10)\end{array}$ & $\begin{array}{l}0.19 * * \\
(0.09)\end{array}$ \\
\hline FDI per capita $\mathrm{t}-1 *$ Formal institutional void $\mathrm{t}-1$ & $\begin{array}{l}0.01 * * \\
(0.003)\end{array}$ & $\begin{array}{c}0.01^{*} \\
(0.003)\end{array}$ & $\begin{array}{c}0.01 * \\
(0.003)\end{array}$ \\
\hline FDI per capita t- $1 *$ Informal institutional void & $\begin{array}{c}0.001 \\
(0.001)\end{array}$ & $\begin{array}{c}0.001 \\
(0.001)\end{array}$ & $\begin{array}{c}0.001 \\
(0.001)\end{array}$ \\
\hline Formal institutional proximity $\mathrm{t}-1$ & & $\begin{array}{c}0.45 \\
(0.46)\end{array}$ & \\
\hline FDI per capita $\mathrm{t}-1 *$ Formal institutional proximity $\mathrm{t}-1$ & & $\begin{array}{c}0.001 \\
(0.003)\end{array}$ & \\
\hline Informal institutional proximity & & & $\begin{array}{l}-0.30 \\
(0.55)\end{array}$ \\
\hline FDI per capita $\mathrm{t}-1 *$ Informal institutional proximity & & & $\begin{array}{l}-0.002 \\
(0.002)\end{array}$ \\
\hline Constant & $\begin{array}{c}65.33 * * * \\
(9.92)\end{array}$ & $\begin{array}{c}53.60 * * * \\
(11.85)\end{array}$ & $\begin{array}{c}69.70^{* * * *} \\
(9.70)\end{array}$ \\
\hline Observations & 1,326 & 1,105 & 1,326 \\
\hline Number of pair countries & 221 & 221 & 221 \\
\hline $\operatorname{AR}(1)$ & -5.42 & -4.85 & -5.41 \\
\hline $\operatorname{AR}(2)$ & 1.02 & 0.09 & 1.04 \\
\hline Wald test & 220.90 & 219.85 & 220.87 \\
\hline
\end{tabular}

Source: Authors' calculation.

Notes: Dependent variable $\Delta$ Access to electricity. Two-step system-GMM. Robust standard errors in parentheses.

All AR(1) test statistics statistically significant at the 1 per cent level. All AR(2) test statistics statistically insignificant.

All Hansen test statistics statistically insignificant.

*** Significant at 1 per cent level. ** Significant at 5 per cent level. * Significant at 10 per cent level. 
Table 10. Alternative measure of quality of informal institutions: Marginal effects of FDI per capita.

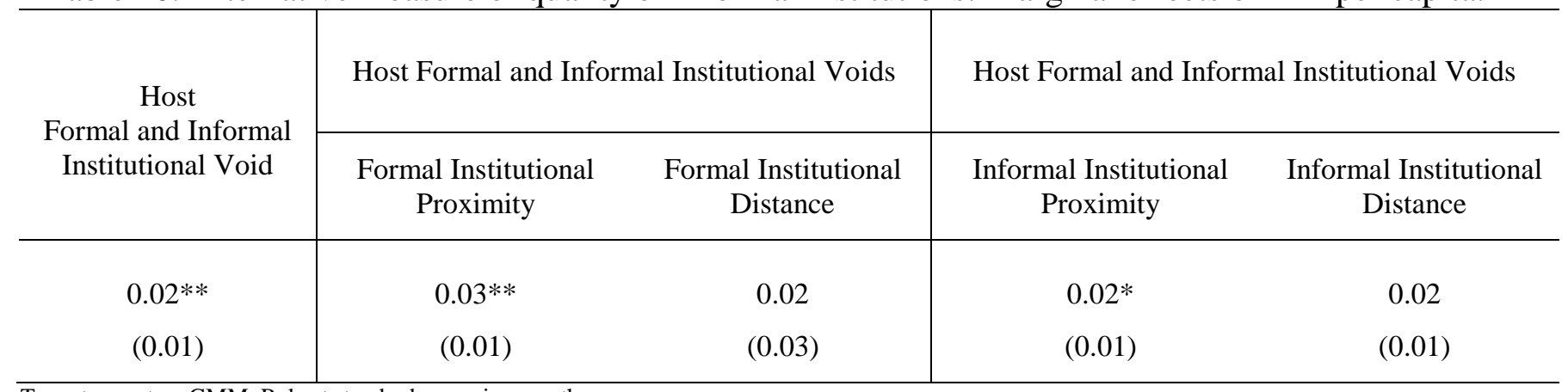

Two-step system GMM. Robust standard errors in parentheses.

*** Significant at 1 per cent level. ** Significant at 5 per cent level. * Significant at 10 per cent level. 


\section{Appendix}

Table A.1. Formal institutional dimensions of the provision of electricity infrastructure

\begin{tabular}{|c|c|c|}
\hline $\begin{array}{c}\text { WORLDWIDE } \\
\text { GOVERNANCE } \\
\text { INDICATORS (WGIS) }\end{array}$ & WGI DEFINITIONA & $\begin{array}{l}\text { FORMAL INSTITUTIONAL } \\
\text { DIMENSIONS }^{\mathrm{B}}\end{array}$ \\
\hline $\begin{array}{l}\text { Government } \\
\text { Effectiveness }\end{array}$ & $\begin{array}{l}\text { Quality of public and civil services and the degree } \\
\text { of their independence from political pressures. } \\
\text { Quality of policy formulation and implementation, } \\
\text { and the credibility of the government's commitment } \\
\text { to such policies. }\end{array}$ & $\begin{array}{l}\text { Government's ability in } \\
\text { directly providing electricity; } \\
\text { Credibility of regulatory } \\
\text { system. }\end{array}$ \\
\hline $\begin{array}{l}\text { Political Stability and } \\
\text { Absence of Violence and } \\
\text { Terrorism }\end{array}$ & $\begin{array}{l}\text { Likelihood of political instability and/or politically } \\
\text { motivated violence, including terrorism. }\end{array}$ & Political stability. \\
\hline Voice and Accountability & $\begin{array}{l}\text { Extent to which a country's citizens are able to } \\
\text { participate in selecting their government, as well as } \\
\text { freedom of expression, freedom of association, and } \\
\text { a free media. }\end{array}$ & $\begin{array}{l}\text { Administrative capabilities of } \\
\text { the country; Judicial } \\
\text { independence and } \\
\text { professionalism. }\end{array}$ \\
\hline Regulatory Quality & $\begin{array}{l}\text { Ability of the government to formulate and } \\
\text { implement sound policies and regulations that } \\
\text { permit and promote private sector development. }\end{array}$ & $\begin{array}{l}\text { Credibility of regulatory } \\
\text { system. }\end{array}$ \\
\hline Control of Corruption & $\begin{array}{l}\text { Extent to which public power is exercised for } \\
\text { private gain as well as 'capture' of the state by elites } \\
\text { and private interests. }\end{array}$ & $\begin{array}{l}\text { Credibility of regulatory } \\
\text { system; Judicial } \\
\text { independence and } \\
\text { professionalism. }\end{array}$ \\
\hline Rule of Law & $\begin{array}{l}\text { Extent to which agents have confidence in and } \\
\text { abide by the rules of society, and in particular the } \\
\text { quality of contract enforcement, property rights, the } \\
\text { police, and the courts, as well as the likelihood of } \\
\text { crime and violence. }\end{array}$ & $\begin{array}{l}\text { Administrative capabilities of } \\
\text { the country; Judicial } \\
\text { independence and } \\
\text { professionalism. }\end{array}$ \\
\hline
\end{tabular}

